\title{
STOSUNEK ŚW. AMBROŻEGO DO MAŁŻEŃSTWA I ŻYCIA RODZINNEGO
}

Niektóre wypowiedzi i wyrażenia św. Ambrożego, biskupa Mediolanu /374-397/ oraz jego szczególny entuzjazm w propargowaniu dziewictwa zrodziły zarzuty, że deprecjonuje małżeństwo 1 gardzi nim. Pojawiły się one już za życia Mediolańczyka i nadal powracaja w opracowaniach ${ }^{1}$.

Postawmy sobie pytanie, czy św. Ambroży, entuzjasta idei dziewictwa, rzeczywiście negował wartość małżeństwa? Jak należy rozumieć takie fakty, że określa nieraz małżeństwo jako stan przeznaczony dla ludzi słabszych i służący tylko godziwemu uśmierzeniu pożądliwości, że uwypukla jego niedogodności, ciężary, utrapienia, że nazywa go zniewoleniem, kajdanami? Są to pytania, na które należy podjąć próbę odpowiedzi, zwłaszcza gdy przystępujemy do rewaloryzacji starochrześcijańskiej myśli o małżeństwie i życiu rodzinnym。

Pewne wyjaśnienie zarzutów w tym wgględzie daje kontekst epoki. Anachronizmem jest patrzeć na IV wiek w świetle obecnej, szeroko rozwiniętej i ogromnie dowartościowanej teologii i etyki małżenskiej.

Nieco usprawiedliwienia wnosi fakt, że zarzuty wobec stanu małżeńskiego nie były wymysłem św. Ambrożego。 Powielał on bowiem

1 Por. G.Boissier, La fin du paganisme, t.2, Paris 1894, 364-365. Szerzej o zarzutach stawianych św.Ambrożemu zob.: A.Paredi, Saint Ambrose, his 1 ife and times, Notre Dame 1964, 148-150; V.Monachino, S.Ambrogio e la cura pastorale a Milano nel secolo IV, Milano 1973, 168-173. Paredi i Monachino bronia biskupa mediolańskiego zestawiając i analizując poszczególne jego wypowiedzi. Wydaje się, że konieczne jest nadto nakreślenie pewnych założeń ogólnych, co jest zamierzeniem niniejszego komunikatu. 
argumenty pogańskiej krytyki małżeństwa, przewijającej się od epoki solistów, poprzez diatrybę cynicko-stoicką wypowiedziach wielu pisarzy 1 P1lozofów.

Zarzuty lagodzi także kontekst nauki ascetycznej biskupa Mediolanu, głoszącego porściagliwość, opanowanio namiegtności i rozkoszy cielesnych, oderwanie od świata. Biskup kierował się tu nie tylko potęźna wówczas tendencją ucieczki od świata, ciała czy namiętności, ale tworzył przeciwage dla laksystycznej moralności Helwidiusza, Bonozusa, Jowiniana $i$ ich zwolenników.

Powyzsze odpowiedzi będące jednak jedynie usprawiedliwieniem, częściowo tylko daja odpowiedź na pytanie, czy św. Ambroży był zwolennikiem, czy przeciwnikiem małżéstwa.

Punkt wyjścia dla odpowiedzi na postawione pytania stanowi spostrzezenie, że św. Ambroży, jeżeli krytykował stan małżeński, to jedynie jego stronę praktyczno-moralną, podkreślając ciężar I niedogodności, jakie ze sobz niesie; nigdy zaś nie dotykał istoty małzeństwa. Wprost przeciwnie, głosił, że jest ono ze swej istoty dobrem 1 potępiał tych, którzy nie dostrzegają jego wartości, a nawet go odrzucają ${ }^{2}$. Nie ma u św. Ambrożego manichejsiciej, pesymistycznej koncepcji płci czy spraw cielesnych. Do dziewictwa wzywał ze względów czysto ewangelicznych - "ze względu na Królestwo Boże" - rozwijając idee mistycznych zaślubin z Bogiem. Dziewictwu nie nadawał charakteru antyseksualnego, nie widział w nim stanu negatywnego w stosunku do małżéstwa ${ }^{3}$.

Ogromnie ważna jest wreszcie sprawa natury metodologicznej. Chodzi mianowicie o to, że sposób potraktowania małżeństwa i życia rodzinnego jest uzaleźniony zarówno od głównego celu $i$ tematyki "dzieła, jak i zanierzeń autora. Wiadomo, że biskup Mediolanu

2 Por. De viduis 13,81, PL 16,273: "Non ergo copula nuptialis quasi culpa vitanda, sed quasi necessitatis sarcina declinanda"; De virginibus I, 7,34-35, PL 16, 209: "Dicet aliquis: Ergo dissuades nuptias? Ego vero suadeo, et eos damno qui dissuadere consuerunt ... Qui enim copulam damnat, damnat et filios ... Non itaque dissuadeo nuptias, sed Pructus sacratae virginitatis enumero ... Bona cum bonis comparo".

3 Por. De virginitate 6,28, PL 16,287: "Est ergo praeclara militia, quae regno coelorum militat". Por. A.Bober, Antologia patrystyczna, Kraków 1965, 163: "Dziewictwo jest dla niego [św. Ambrożego] cnotí aktywní, jest chwalebna walka o królestío niebieskie". 
nie zajmował się oddzielnie sprawa małżéstwa. Pozostawił jedynie fragmentarycznie sformułowane poglądy, które wyrażał zasadniczo przy dwóch okazjach: po pierwsze, gdy komentował odpowiednie fragmenty Pisma św. lub gdy był konsultowany w sprawie małżéstwa i musiał dać pisemnat odpowiedź/czyli wchodzą tu komentarze i listy/, po drugie, gdy zacizcał do dziewictwa czy wytrwania w stanie wdowieństwa, lub gdy bronił godności tych stanów ${ }^{4}$. Z tych dwóch rodzajów wypowiedzi nie trudno dostrzec, że ukazują one jak̆by dwa różne stanowiska wobec małżeństwa i rodziny.

W pierwszym rodzaju pism św. Ambroży przedstawiał małżeństwo 1 rodzinę pozytywnie. Głosił, że małżeństwo jest rzeczywistościa świętą, stworzoną od początku przez Boga, uświęconą i wyniesioną przez Jezusa. Bronił trwałości instytucji małzeństwa, nauczał o równości małżonków ${ }^{5}$. Mówił, że dzieci sa radościa matki, łaska i błogosławieństwem małżeństwa, z upodobaniem sławił ideę macierzyństwa ${ }^{6}$. U św. Ambrożego zasięgano również porad w sprawach zwizzanych z małżéstwem. Stąd wiadomo, że uchodził za autorytet także i w tej dziedzinie ${ }^{7}$.

4 Por. traktaty: De virginibus, De virginitate, De institutione virginis, Exhortatio virginitatis, De viduis, Epistulae: 42,56, 56 a /De Bonoso episcopo/, 63.

5 Według K.P.Schneidera, św. Ambroży niżej stawiał kobiet mężyznę/Christiiches Liebesgebot und weltilche Ordnungen. Historische Untersuchungen zu Ambrosius von Mailand, Koln 1975, 82-90./L.F.Pizzolato przypomina natomiast nauke biskupa Mediolanu o wzajemny dopełnianiu sie mężcyzny i kobiety małżé́stwie /La coppia umana in sant Ambrogio, w: Etica sessuale e matrimonio nel cristianesimo delle origini, Milano 1976, 180-211/. Jak zauwaža nałto Pizzolato, żywe sa u św. Ambrożego symbole przejęte od Filona: rozum - mężcyzna, zmysły - kobieta. Biskup Modiolanu nie stwierdzał więc wyższości méżcyzny nad kobieta w porządku ontologicznym, ale raczej wyższość moralną męskości nad żeńskością. Kategorie zaś męskości i żeńskości znajdujaz się w jakimś stopniu zarówno w mężcyźnie jak i kobiecie/tamże 185/.

6 Równiez w eklezjologii św. Ambroży szczególnie podkreślał macierzyństwo Kościoła, por. A。Santorski, Odkupienie czlowieka w nauce św. Ambrożego, w: Drogi zbawienta, Poznań-Warszava-Lublin $1970,335-366$.

7 Por. odpowiedzi, jakich w sprawach związanych z mazceństwem udzielił św. Ambroży Wigiliuszowi, biskupowi Trydentu oraz Paternusowi /chodzi zapewne o prokonsula Apryki z 393 r./: Epistola 19 i 60: PL 16,1024-1036 i 1234-1237 oraz 1 ist do pevnego Syzyniusza zagniewanego na swego syna, że wybrał żonę bez ojcowskiej zgody: Epistola 83: PL 16,1335-1338. 
W pisfach natomiast traktujacych o godności dziewictwa przeważa całkier odmienny, nieraz wprost przecinny, obraz małżéstwa. Tu jest ono zniewalającym jarzmem, kajdanami, ograniczenien wolności, przeszkodą w zjednoczeniu z Bogien, instytucją dla słabszych, lekarstwera na pożądliwość. Tu autor opisuje przerażające bóle rolzenia, kłopoty wychowania dzieci, ciężar powinności małżeńskich. oczywiście, taki obraz małżeństwa biskup rysował przemawiając do dziewic lub poświeconych wdów/jak wiadomo, pisma św. Ambrożego składaja sie z kazań/. Chcial je w ten sposób przekonać i utwierdzić w wyborze drogi życia oraz zachęcić do wytrwałości. Nigdy nie kierował takich wypowiedzi do ogółu wiernych, do małżonków, ani też do przygotowujacych siz do nałżeństwa. Stąd wniosek, że tego rodzaju wypcwiedzi nie maja charakteru programowego, deklaratywnego na temat małżeństwa, i nie nożna je za takie uważać. Nie wolno na ich podstawie buciować poglazdu o negatywnym stosunku biskupa do tego stanu.

Zwróćmy też uwage na użycie słownictwa w obu omawianych rodzajach wypowiedzi, np. słowa "servitus" = "stan niewoli". T.H.Duden uważał, że biskup sediolanu często $i z$ upodobaniem określał tym mianem małżeństwo, przytaczając ten fakt jako argument świadczący - negatywnym stosunku Mediolańczyka do związku dwojga ludzi ${ }^{8}$. Takie określenie małżéstwa występuje jednak tylko w pismach poświecconych dziewictwu. Nie pojawia się w komentarzach ani w listach, zawierajacych obiektywne wypowiedzi o małżeństwie. Podobną interpretacje przyjmuja inne określenia, jak "iugum", "vinculum". Użyte na oznaczenie małżeństwa określają moc i wartość węzła małżeńskiego, uwypuklaja konieczność zgody, wierności, stałości. Terminy te zaś użyte wismach traktujących o godności dziewictwa przybieraja sens pejoratywny; maja znaczenie zniewalającego jarzma, kajdan, niewoli ciata i ducha 9 .

Dochodzimy do kolejnego pytania: jeżeli św. Ambroży wtedy,

8 T.H.Dudden, The life and times of S.Ambrose, t.2, Oxford 1935. 139.

9 Analiza użycia wzmiankowanych określeń jest prizedmiotem pracy: J.Naunowicz, Hyrażenia na oznaczenie małżeństwa u św. Ambrożego, Lublin 1980 /mps BKUL/. 
gdy mówił wprost i bezpośrednio o małżéstwie, wyporiadał sie pozytywnie o tyri stanie, to jaka funkcję mają wyrażenia negatywne o małżeństwie w wypowiedziach poświęconych dziewictwu? Główną rolę odgrywaja tu konwencje starożtnej retoryki, w jakich te wypowiedzi zostały ułożone. Pisla traktujące o godności dziewictwa maja charakter pochwały /panegiryku/ oraz zachęty/protreptyku/. Według utartych schematów retorycznych, przekonywanie, pochwała i zachęta polegały często na podkreślaniu, wyjaskrawianiu i wyolbrzymianiu /auxesis, amplificatio/wad, ułomności i niebezpieczeństw stanu przeciwnego, na jego niemal ośmieszaniu i przedstawianiu w karykaturalnych rysach ${ }^{10}$. Przy takich zasadach argumentowania, stan przeciwny jawił się jako bezwartościowy, szkodliwy, haniebny. Jednak nie o ten stan autorowi chodziło. Narzuca sie tu zasada, którą wprost podaje św. Ambroży mówiąc, iż wypowiedzi tego rodzaju nie są poświęcone zniesławianiu małżeństwa, lecz jedynie zachęcie do dziewictwa: "Non ergo quidem dissuadeo matrimonium, sed virginitatis attexo beneficium"11. Zatem byłoby błędem metodologicznym i niesprawiedliwościa wobec Ambrożego odczytywanie jego stanowiska w perspektywie niezgodnej z jego załoźeniami. Właściwe zaś poglądy biskupa na temat małżenstwa 1 rodziny wynikaja ze wzmiankowanych wyżej jego wypowiedzi pozytywnych.

Mniejszy wpływ na ton pisma, choć teź niebagatelny, miała polemika św. Ambrożego z poglądami Jowiniana, Heløidiusza 1 Bonozusa. Wypowiedzi biskupa poswiecone apologii dziewictwa maja cha-

10 St.Longosz, Inwektywa chrześcijańska, SwP 530-537. Por. też: M.Maykowska, Klasyczna teoria wymowy, Warszawa 1936.

11 De virginibus I 6,24: PL 16,206. Jest rzecza interesujaca, ze w pismach poświęconych dziewictwu jest wiele cennych stwierdzer na temat małżeństwa. Gdy bowiem biskup zasypał argumentami z barwnego porównania obu stanów, przywołał wszystkie ponure strony małzeństwa 1 pogrążył je w mroku, pobudził wobraźnie słuchaczy i wstrząsnął ich uczuciami, zmusił do przyznania racji $i$ do uznania godności dziewictwa, wedy tagodnie $i$ ze spokojem przyznawał, ze małżéstwo jest też dobre i potrzebne. Lecz zazwyczaj na tym nie kończył, jako dobry orator szedł dalej: na tezie o wartości małzeństwa budował dalsze pięra wywodu o godności dziewictwa, które jest przecież stanem wyższym. 
rakter stosunkowo wyważony, jeśli weżmie się pod uwage fakt, że nawymyślanie przeciwnikowi w starożytnej polenice należało niemal do dobrego tonu.

Na zakończenie warto zaznaczyć, że św. Ambroży, jako jeden z pierwszych, dostrzegał zwizzek dziewictwa z małzeństwem. Dziewictwo i celibat według niego nie tylko nie sprzeciwiaja sie małżéstwu, ale podnosza jego godność i wartośćc ${ }^{12}$. Należy też dodać, że stanowisko św. Ambrożego postuluje odpowiedzialne i poważne trástowanie zagadnień i problemów małżeństwa i rodziny, które rzeczywiście wymagaja trudu, poświęcenia i odwagi.

$$
\text { Ks. Józef Naumowicz - Warszawa }
$$

\section{ST.AMBROSE"S ATTITUDE TO MAT IIMONY AND FANILY LIFE /Summary /}

It would be a methodological failure, on the basis of $\mathrm{St}$. Ambrose's works, which aim at encouraging and defending the dignicy of virgins or widows state, to conclude on the author's negative attitude to matrimony and family life. According to ancient rhetoric principles, encouragement and praise frequently consisted in emphasizing and magnifying the disadvantiges, dangers and burdens of opposite state. These negative definitions are therefore rhetoric utterances. They cannot be considered as an instrument of programing or declarativeness in the matter of matrimony and family life. They were never addressed to the spouses or those preparing a marriage;

Roreover, in St.Ambrose's works not devoted to virginity, a positive image of matrimony and family life reigns, emphasizing their dignity, holiness and inherent values.

12 Por. Eyistola 42,3: PL 16,1172: "Sed quae potest laus esse coniugii, si nulla virginitatis est gloria"? 